\title{
Cytotoxicity and Antiproliferation of Phycocyanin from Spirulina platensis Extract on WiDr Colon Cancer Cell Line
}

\author{
Ajeng Kurniasari Putri ${ }^{1,2 *}$, Safira Chairani Dimarti ${ }^{1}$, Renni Yuniati ${ }^{1,3}$, Neni Susilaningsih ${ }^{1,4}$ \\ ${ }^{1}$ Department of Biomedical Science, Faculty of Medicine, Universitas Diponegoro, Indonesia \\ ${ }^{2}$ Research and Development Center for Marine and Fisheries Product Processing and Biotechnology, \\ Kementerian Kelautan dan Perikanan, Indonesia \\ ${ }^{3}$ Department of Dermatology and Venereology, Faculty of Medicine, Universitas Diponegoro, Indonesia \\ ${ }^{4}$ Department of Anatomy and Histology, Faculty of Medicine, Universitas Diponegoro, Indonesia \\ *Email: ajengkp@gmail.com
}

Submitted: 8 January 2020. Revised: 11 February 2020. Accepted: 20 March 2020

\begin{abstract}
Phycocyanin from Spirulina platensis extract has anticancer activity against various types of cancer cell cultures. However study about its effect on colon cancer cell lines, especially the WiDr, has not been reported before. This study aimed to reveal the anticancer activity of phycocyanin from Spirulina platensis extract on WiDr cells. The research was an in vitro experimental study, with the investigation on cytotoxicity also antiproliferation as the anticancer parameters. Both cytotoxicity and antiproliferation test was conducted through MTT assay to observe the visualization and inhibition of proliferation of different concentrations of phycocyanin in several incubation times on the WiDr colon cancer cell line. The obtained data were then processed statistically with the Two Way ANOVA test at a significance value of $\mathrm{p}<0.05$ and followed with the Post Hoc test since there were significant differences. Based on the results, it could be postulated that phycocyanin extracted from freshwater Spirulina platensis was classified as non-toxic (IC I0 of 85 $\mu \mathrm{g} / \mathrm{ml}$ ). Consequently, it is less potential to be used as the treatment for colon cancer. However, phycocyanin could inhibit the proliferation of the WiDr cell for approximately $47.4 \%$, specifically at the concentration of $1710 \mu \mathrm{g} / \mathrm{ml}$ for 72 hours. It could be concluded that freshwater phycocyanin is less effective as an anticancer substance. The benefit of this study is to provide the new scientific evidence of the contrary results of freshwater phycocyanin activity from Spirulina platensis as an anticancer agent of colon cancer.
\end{abstract}

Key words: anticancer; colon cancer; freshwater phycocyanin

How to Cite: Putri, A. K., Dimarti, S. C., Yuniati, R., \& Susilaningsih, N. (2020). Cytotoxicity and Antiproliferation of Phycocyanin from Spirulina platensis Extract on WiDr Colon Cancer Cell Line. Biosaintifika: Journal of Biology \& Biology Education, 12 (1), $42-49$

DOI: http://dx.doi.org/10.15294/biosaintifika.v12i1.22881

\section{INTRODUCTION}

Cancer is the second-highest cause of death globally and causes more than 8.8 million human deaths in 2015, which is equivalent to 1 in 6 deaths that occur in the world (Dewi, et al., 2018). The development of cancer (carcinogenesis) is a multistep process in which a normal cell will transform into cells that express the malignant phenotype. The process is a complete breakdown or dysfunction of controlled stages such as cell differentiation, proliferation, and programmed cell death (apoptosis) as well as the involvement of regular feedback mechanisms, thus causing the cancer cells' rapid growth as well as their metastasis (Nazih \& Bard, 2018). Colorectal cancer (CRC) is the third most common cancer and the fourth most common cause of cancer-related deaths worldwide, also one of the earliest, most molecularly characterized solid tumors (Athauda, et al., 2018). The sequence of development of CRC is gradually from adenoma formation to carcinoma through the accumulation of genetic and epigenetic events (Athauda, et al., 2018).
Cancer treatment with plants and plant-based products is a revolutionary method, besides being simple, safer, environmentally friendly, fast, more selective following its function and could act specifically on tumor cells without affecting healthy cells, it also tends to be non-toxic if compared to conventional treatment methods (Iqbal et al., 2017). One potential phytochemical is derived from several marine sources, mainly algae, because it is known to be able to modulate some cellular mechanisms such as cellular cytotoxics, prevent tumor cell invasion, and increase apoptosis of cancer cells (El-hack et al., 2019). It has been proven in many studies that microalgae activity can fight cancers (breast, ovary, skin, lung, kidney, and stomach) (El-hack et al., 2019; Ying et al., 2016), inhibit cell proliferation and reduce the ability to form colonies in some cancer cells.

Spirulina platensis was classified in the genus Arthrospira (Oscillatoriales) because it meets the phylogenetic and cytological criteria. Spirulina is bluegreen, multicellular, and filamentous microalgae that have a symbiotic relationship with bacteria to bind nitrogen from the air. Spirulina is photosynthetic and 
autotrophic algae. The primary photosynthetic pigment, phycocyanin, also contains chlorophyll and carotenoids (Vo, et al., 2015). Phycocyanin isolated from Spirulina platensis can cause the release of cytochromes $\mathrm{C}$ from mitochondria and caspasedependent induction of apoptosis in $\mathrm{HeLa}$ cells (Nazih \& Bard, 2018; Yang et al., 2014; Dewi et al., 2018). Ethanolic extract of $70 \%$ Spirulina showed significant cytotoxicity in K562 and Kasumi-1 cell cultures. $\mathrm{IC}_{50}$ values obtained using blue trypan solution were $4.64 \mathrm{mg} / \mathrm{mL}$ for K-562 and $3.68 \mathrm{mg} / \mathrm{mL}$ for Kusumi-1 cell lines. Aqueous extract from Spirulina also showed cytotoxicity using the blue trypan method, at a higher dose, where the $\mathrm{IC}_{50}$ value obtained was $12.68 \mathrm{mg} / \mathrm{mL}$ for K-562 and $2.13 \mathrm{mg} /$ $\mathrm{mL}$ for Kusumi-1 cell lines. $\mathrm{IC}_{50}$ value of $70 \%$ ethanolic extract Spirulina with the MTT test method was $0.40 \mathrm{mg} / \mathrm{mL}$ for K-562 and $0.31 \mathrm{mg} / \mathrm{mL}$ for Kusumi-1 cell lines. While the $\mathrm{IC}_{50}$ value with the MTT test method for Spirulina water extract was slightly higher at $15.77 \mathrm{mg} / \mathrm{mL}$ for K-562 and $9.44 \mathrm{mg} / \mathrm{mL}$ for Kusumi-1 cell lines (Yohana, et al., 2016). Other studies also provide evidence of the anti-cancer activity of commercial Spirulina products against lung cancer cells, especially those related to the chemopreventive properties of Spirulina (Czerwonka et al., 2018). The cytotoxic effects of Spirulina ethanolic extract are quite similar to the effects of the use of cyclophosphamide, a chemical compound used as an anticancer agent. The cytotoxicity obtained from Spirulina extracts against cancer cell lines may be due to the presence of phytopigments (carotenoids, chlorophyll, and phycocyanin), as well as the polysaccharides that are constituents in these extracts (Yohana, et al., 2016). The results of other studies suggest that the combination of phycocyanin and all-trans-retinoic acid (ATRA) might have an inhibitory effect on HeLa cell growth by inhibiting cell cycle growth, inducing cell apoptosis, and promoting complement-mediated cytolysis (Yang et al., 2014). Besides, phytochemical screening results also showed the presence of tannins, flavonoids, steroids, glycosides, saponins, and alkaloids in Spirulina platensis ethanolic extract (Fithriani, et al., 2015). Antioxidant activity $\left(\mathrm{IC}_{50}\right)$, antioxidant capacity (FRAP test) and total phenolic content found in the ethanolic extract of Spirulina sp. with successive values are $518.94 \mathrm{ppm}, 49.95 \pm 2.02$ ( $\mu$ mol Fe $2+$ eq.g-1 DW) and $0.32 \pm 0.0025 \mathrm{mg} \mathrm{GAE}$ g-1 DW (Fithriani, et al., 2015). Based on the results of these previous studies, it could be concluded that Spirulina has the potential to be one source that can be developed into an anticancer drug (Yohana et al., 2016).

Colon cancer, as cancer with a high incidence in Indonesia, requires appropriate treatment for its sufferers, especially therapies with little side effects and made from a natural product. Therefore, it is necessary to develop therapies from herbal ingredients that have the potential to kill cancer cells at the in vitro level. Phycocyanin from Spirulina platensis extract has anticancer activity against various types of cancer cell cultures. However, the activity of antiproliferation as one of the anticancer components of phycocyanin in WiDr colon cancer cell cultures has not been reported before. Therefore, this study aimed to reveal the anticancer activity of phycocyanin from Spirulina platensis extract on WiDr cells. After all, the benefit of this study is to provide scientific information regarding the potency of phycocyanin from Spirulina platensis extract as an anticancer agent for colon cancer.

\section{METHODS}

\section{Cell lines}

This study used the population of WiDr (colon cancer cell line) cell cultures that were in the living and confluent state and attached to cell culture flask. WiDr cells obtained from the Laboratory of Parasitology, Faculty of Medicine, Gadjah Mada University, were isolated, then cultured in cell culture flask using a complete medium (RPMI $1640+$ FBS + fungizone + penstrep) and incubated in a $\mathrm{CO}_{2}$ incubator at $37^{\circ} \mathrm{C}$ and $\mathrm{CO}_{2}$ concentration of $5 \%$.

\section{Phycocyanin Preparation}

Phycocyanin extraction from Spirulina platensis was carried out according to the method of Rahmawati, Hidayatullah, \& Suprayatmi (2017), with modification. Furthermore, Phycocyanin was identified using high-performance liquid chromatography (HPLC) according to the modified method by Izadi and Fazilati (2018).

Spirulina platensis was collected from aquaculture ponds in Sukoharjo, Jawa Tengah, and separated from the growth medium. A total of 10 grams of Spirulina platensis was dried, then macerated in doubledistilled water for 1 hour in a water bath at $26^{\circ} \mathrm{C}$ with a ratio of $1 \mathrm{~L}$ of double-distilled water for 10 grams of Spirulina platensis.

The results of maceration thereafter were dried using a freeze dryer for 24 hours at a temperature of $4{ }^{\circ} \mathrm{C}$ until reaching a yield of $40 \%$. After freezing, the frozen sample was thawed at room temperature for 15 minutes. Afterward, the sample was centrifuged for 30 minutes at $3000 \mathrm{rpm}$.

Spirulina platensis extract was then processed by HPLC using a C18 column $(250 \times 4.6 \mathrm{~mm})$ with a mobile phase in the form of a mixture of methanol and ammonium acetate $3 \%$ (ratio $7: 3, \mathrm{v} / \mathrm{v}$ ) at $25^{\circ} \mathrm{C}$ and longwave of $615 \mathrm{~nm}$. 


\section{Cytotoxicity of Phycocyanin}

Cytotoxicity analysis was performed using the MTT assay method, according to Wulandari, Meiftasari, Fadliyah, \& Jenie (2018). WiDr cells were seeded in 96-well plate at a density of $1 \times 10^{4}$ cells / 100 $\mu \mathrm{L} /$ well and were incubated in a $\mathrm{CO}_{2}$ incubator at $37^{\circ} \mathrm{C}$ and $\mathrm{CO}_{2}$ concentration of $5 \%$ for 24 hours.

Cells were treated with increasing concentrations of phycocyanin $(1.95 ; 3.91 ; 7.81 ; 15.63 ; 31.25 ; 62.5$; $125 ; 250 ; 500$; and $1000 \mu \mathrm{g} / \mathrm{mL}$ ) and doxorubicin of $100 \mu \mathrm{g} / \mathrm{mL}$. Following 24 hours of incubation, the medium of culture was removed, and cells were washed with PBS (Sigma).

Afterward, cells were added with $100 \mu \mathrm{L}$ MTT (Sigma) $5 \mathrm{mg} / \mathrm{mL}$, diluted with culture medium in each well for 4 hours. At this stage, the condition of the cell was examined and documented using an inverted microscope, mainly to determine the formation of crystalline formazone. When formazone crystals had formed, the test was continued by adding $100 \mu \mathrm{L}$ of stopper solution (10\% SDS dissolved in $0.1 \mathrm{~N}$ $\mathrm{HCl})$ to each well. WiDr cell cultures in plates were then incubated in a dark place overnight.

Later on, the absorbance of each well was measured using the ELISA reader at $595 \mathrm{~nm}$ (Bio-Rad) (Widiyastuti, et al., 2019). The single absorbance data was converted into the percentage of cell viability and was used to determine the $\mathrm{IC}_{50}$ value based on (AAT Bioquest, 2019). The number of replications for each different treatment was four times.

\section{Antiproliferation of Phycocyanin to WiDr Cell Line}

Antiproliferation analysis was also performed using the MTT assay method following the cytotoxicity procedure. The concentration range of the test substance given was $1 / 2 \mathrm{IC}_{50}, \mathrm{IC}_{50}$, and $2 \mathrm{x} \mathrm{IC}_{50}$. Moreover, the antiproliferation test was conducted in three different incubation times of 24,48 , also 72 hours.

After incubation, the absorbance reading for each well was performed using an ELISA reader with a wavelength $(\lambda)$ of $595 \mathrm{~nm}$, to determine the percentage of cell viability, besides the percentage of inhibition relative to control (Wulandari et al., 2018).

\section{Statistical Analysis}

Data as the results of cytotoxicity and antiproliferation tests were processed statistically and presented in the form of images and figures as well as descriptive explanations. The absorbance value in the cytotoxicity test was analyzed using Microsoft Excel to calculate the percentage of cell viability, according to the following formula:

$\%$ cell viability $=($ treatment absorbance-medium control absorbance)/(cell control absorbance- medium control absorbance) X 100
The cell viability values were tested in AAT Bioquest IC $_{50}$ calculator AAT Bioquest (2019), as followed Nikolova et al. (2019); Luparello et al. (2019), to obtain $\mathrm{IC}_{50}$ levels, which then be used in antiproliferation testing. Cell viability calculations were also performed on the absorbance results in the antiproliferation test. The percentage of cell viability relative to control at incubation times of 24,48 , and 72 hours, was made to determine the inhibition among the treatments. The results of cell viability analysis in the antiproliferation test were continued with the Two Way ANOVA test at a significance value of $p<0.05$ and followed with the Post Hoc test since there were significant differences.

\section{RESULT AND DISCUSSION}

WiDr cell was used as a signature type of colon cancer culture cell in this study due to its precise character, besides it has been developed and widely used in various anticancer activity studies in vitro. WiDr cells are cancer cells in humans that are isolated from colonic epithelial tissue in women aged 78 years. WiDr cells have p53 gene mutations and are responsive to chemotherapy (Ekowati et al., 2012). One of the characteristics is the overexpression of cyclooxygenase-2 (COX-2), where COX-2 expression can increase growth factor signaling, cancer cells proliferation, resistance to apoptosis, and metastases that lead to the development of colon cancer (Karpisheh et al., 2019; American Type Culture Collection, 2019; Ekowati et al., 2012). Phycocyanin-rich Spirulina is a reliable free radical scavenger that can inhibit lipid peroxidation in microsomes. Phycocyanin helps protect kidney failure caused by certain drugs, as well as having an anticancer activity (Udayan, et al., 2017).

C-phycocyanin

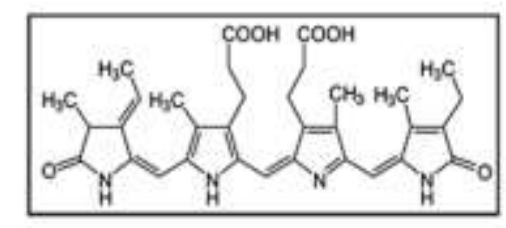

Figure 1. Structure of Phycocyanin from Spirulina platensis (Ercolano, et al., 2019)

\section{Cytotoxicity of Phycocyanin from Spirulina platen- sis on WiDr Cell Line}

According to the equation using the AAT Bioquest $\mathrm{IC}_{50}$ calculator (AAT Bioquest, 2019), it was known that the $\mathrm{IC}_{50}$ of phycocyanin on WiDr cell line was $855 \mu \mathrm{g} / \mathrm{ml}$ (Figure 2.). The $\mathrm{IC}_{50}$ value indicates the half-maximal inhibitory concentration that measures the effectiveness of a substance in inhibiting a specific biological or biochemical function. It represents the concentration of a substance or drug that is required 
for $50 \%$ inhibition in vitro (Zaid, Hammad, \& Sharaf, 2015). Therefore, the cytotoxic effect of phycocyanin is categorized as practically non-toxic (more than 500 $\mu \mathrm{g} / \mathrm{ml})$. However, this also means the substance of phycocyanin was not adequately potential for anticancer on WiDr cell, though this compound is safe to be ingested by the consumer.

The relatively non-potential effect of phycocyanin, possibly highly related to the source and habitat of Spirulina platensis that has been used in this study. The habitat and environment take large enrollments on the bioactive effect of the substances (Paliwal et al., 2017; Manirafasha et al., 2018; Papadaki et al., 2017). In this study, the Spirulina platensis had been cultivated on the freshwater population in Sukoharjo, Jawa Tengah, away from its origin. Microalgae, due to various environmental stresses, regularly adjust their cellular mechanisms to deal with them. The accumulation of the stress metabolites is closely related to the changes occurring in their metabolic pathways. The biosynthesis of metabolites can be triggered by some abiotic stresses like temperature, salinity, UVradiation, and nutrient deprivation (Paliwal et al., 2017). The abiotic factor of $\mathrm{pH}$, salt, and temperature would affect the microalgae to produce substances, which highly potential on some cancer cell line culture. Meanwhile, the freshwater cultivation of microalgae tends to produce fewer stress metabolites that effectively affect the cancer cell line culture. It is correlated with the study of Cahyaningrum (2019), which revealed that the extract of freshwater Spirulina platensis has the weak cytotoxicity of breast cancer culture cell of T47D.

\section{Antiproliferation of Phycocyanin}

The antiproliferation activity of phycocyanin was conducted on various treatments of $1750 \mu \mathrm{g} / \mathrm{ml}, 855$ $\mu \mathrm{g} / \mathrm{ml}$, and $427.5 \mu \mathrm{g} / \mathrm{ml}$ of phycocyanin, doxorubicin, control of cells, also medium of control. Based on Figure 3, it is known that amongst the treatments, the intervention of doxorubicin $(100 \mu \mathrm{g} / \mathrm{ml})$ showed most of the cell death. On the other hand, the treatments of 1710,855 , and $427.5 \mu \mathrm{g} / \mathrm{ml}$ phycocyanin indicated similarity in comparison with the control of the cell, which represents more living cells. Doxorubicin is recognized as a positive control due to its mechanism on various cancer cells. However, doxorubicin has several side effects, such as immunosuppression, nauseous, and reversible arrhythmia. Moreover, longterm use of doxorubicin causes cardiomyopathy effect, followed by heart failure (Mutiah \& Widyawaruyanti, 2017; Wulandari et al., 2018). As shown in Figure 3, the dead cells were shrunk and compact; meanwhile, the live cells were rounded and clear on the center of the cell. The visualizations were related to the weak toxicity of phycocyanin; therefore, the treatments of several concentrations of phycocyanin were not effectively destroying the WiDr cells. Moreover, the higher concentration of phycocyanin could increase the death of the cell. Nevertheless, it would visually be acclaimed that the control cell has a similar appearance in comparison with the cells that had been treated with the phycocyanin.

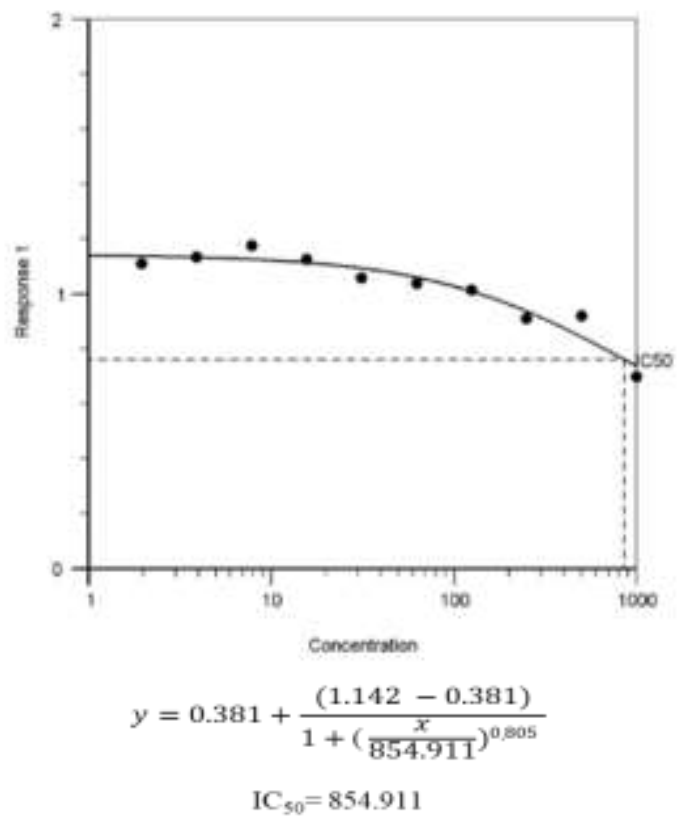

Figure 2. The $\mathrm{IC}_{50}$ equation of phycocyanin on WiDr colon cancer cell line

To examine the anti-proliferation activity of phycocyanin with the consideration of dose- and timedependent incubation; therefore, the percentage of cell viability relative to control amongst the treatments was analyzed as presented in Figure 4. Based on Figure 4a., it is shown that the longer the time of incubation would decrease cell viability up to $52.6 \%$ at the concentration of $1710 \mu \mathrm{g} / \mathrm{ml}$ after 72 hours; hereafter, the incubation significantly $(\mathrm{P}<0.05)$ affects the viability of the cell. Though the results of 24 and 48 hours of incubation were not significantly different, the incubation time of 72 hours was significantly the most effective time for treating the WiDr cell with phycocyanin. The results also represent the effect of phycocyanin to reduce the cell cycle at the concentration above $1000 \mu \mathrm{g} / \mathrm{ml}$, as stated by Czerwonka et al. (2018). It is clearly described in Figure 4b., the higher the concentration of phycocyanin treatments, could decrease the cell viability significantly $(\mathrm{P}<0.05)$. Among the various concentrations, the treatment of two times $\mathrm{IC}_{50}$ of $1710 \mu \mathrm{g} / \mathrm{ml}$ was the most potent to lessen the viability of the WiDr cell. However, the treatment of phycocyanin could not compete for the efficiency of doxorubicin, which has decreased the cell up to $1.3 \%$. It is in line with the non-toxic character of freshwater phycocyanin used in this study. 

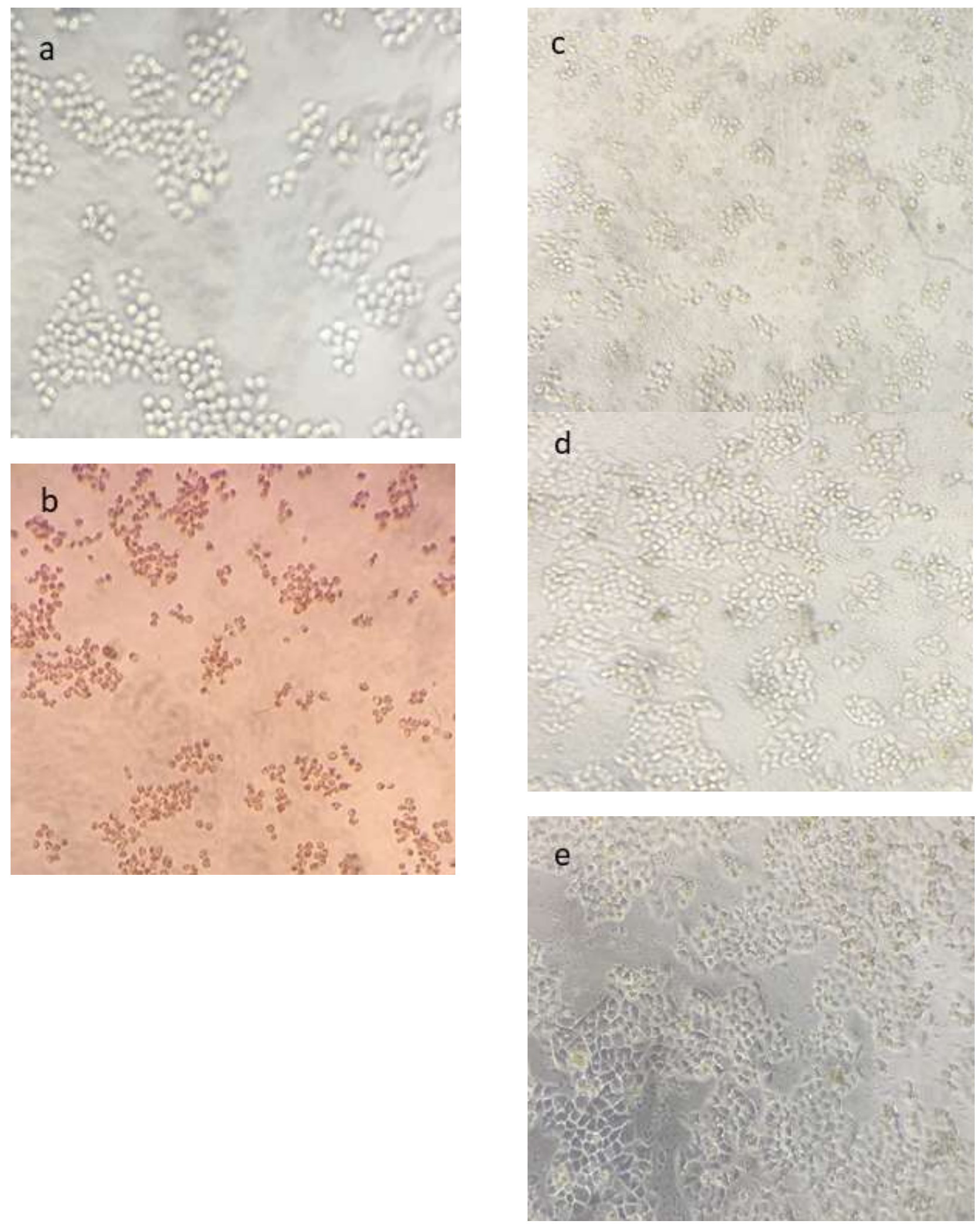

Figure 3. Visualization of WiDr cells in several treatments (a) control cell; (b) doxorubicin of $100 \mu \mathrm{g} / \mathrm{ml}$; (c) phycocyanin of $1710 \mu \mathrm{g} / \mathrm{ml}$; (d) phycocyanin of $855 \mu \mathrm{g} / \mathrm{ml}$; and (e) phycocyanin of $427.5 \mu \mathrm{g} / \mathrm{ml}$. 


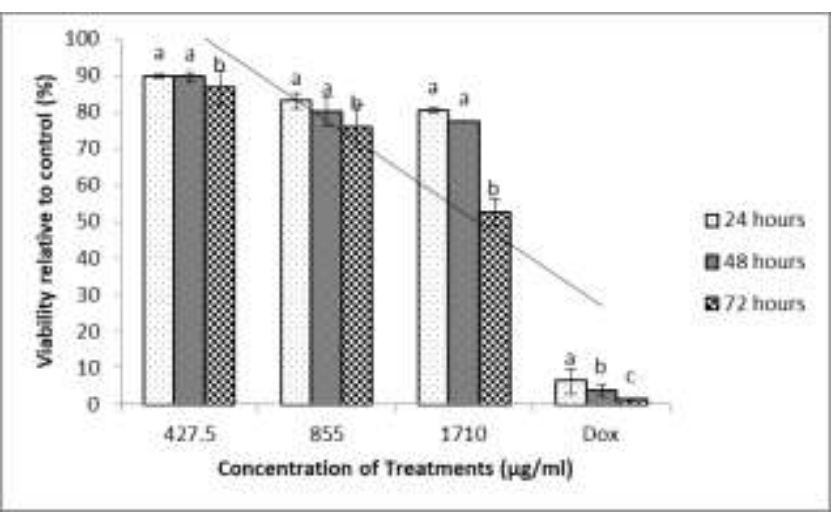

(a) Different font indicates significance at the 0.05 level

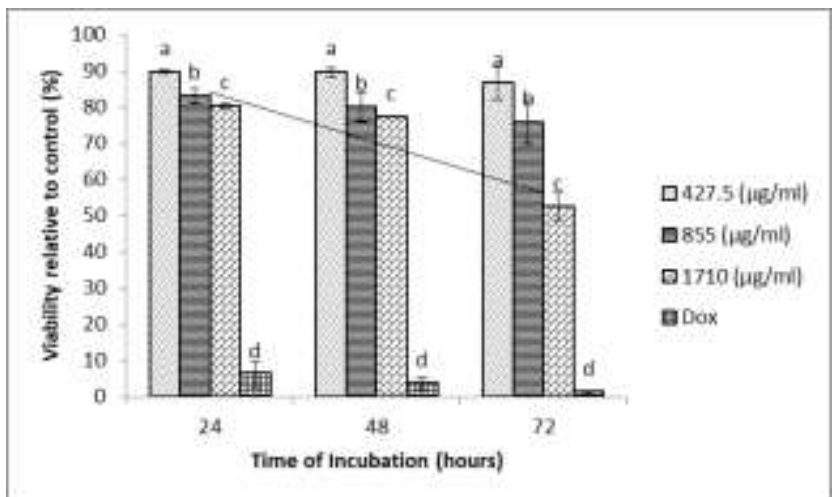

(b) Different font indicates significance at the 0.05 level

Figure 4. WiDr Cell viability in (a) treatments of doxorubicin and phycocyanin of 1710,855 , and 427.5 $\mu \mathrm{g} / \mathrm{ml}$; (b) various incubation times of 24,48 , and 72 hours.

The proliferation of cancer cells is determined and controlled by the mechanism of the multiplying process of cell division. Cell proliferation phases M, G1, $\mathrm{S}, \mathrm{G} 2$, are regulated by genes, protein stimulators, and proliferation inhibitors (CDK protein groups). So, if there is damage to the regulation of cell proliferation, it would form uncontrolled cell growth or cancer. In general, the mechanism of antiproliferation is adjusted to the phase of cell division, where p53 protein is responsible for stopping the cell cycle in the G1 phase while the $S$ phase could be cut cycles through induction replication stress (RS) (Thangam et al., 2013). Besides, the inhibition of the formation of spindle yarn might be used as a barrier to the cell cycle in the G2 phase (Thangam et al., 2013).

\section{Percentage of Phycocyanin Inhibition}

The percentage of inhibition activity of phycocyanin to WiDr cell is presented in Figure 5. The results showed that the most effective inhibition $(47.4 \%)$ was observed when cells were treated with the highest phycocyanin concentration $(1710 \mu \mathrm{g} / \mathrm{ml})$ after 72 hours of incubation. However, these results could not be compared with the doxorubicin treatment that inhibited WiDr cell up to $98 \%$ after 72 hours of incuba- tion. This result is in line with previous studies that stated that the longer time of incubation also the higher the dose of phycocyanin would increase the inhibition of culture cancel cell (Thangam et al., 2013; Ravi et al., 2015; Yang et al., 2014).

The results of this study showed that the treatment of phycocyanin has weak antiproliferative activity on WiDr cells. It is reasonably due to the use of freshwater phycocyanin obtained from the cultivation of Spirulina platensis. The content of chlorophyll and phycocyanin mainly influences the color of Spirulina platensis biomass. Freshwater Spirulina platensis could produce phycocyanin with content and morphology that are almost similar to marine phycocyanin (Ekantari, Marsono, Pranoto, \& Harmayani, 2017). Spirulina platensis from freshwater aquaculture consists of phycobiliprotein pigment-containing phycocyanin pigment with a maximum $\lambda$ value of 615 $\mathrm{nm}$. Based on the absorption at the maximum wavelength obtained by measuring the absorption of the solution at a wavelength of $650 \mathrm{~nm}$, it could be calculated levels of phycocyanin pigments, which is equal to $6.6663 \mathrm{mg} / \mathrm{g}$ wet Spirulina platensis weight biomass (Agustini, 2007).

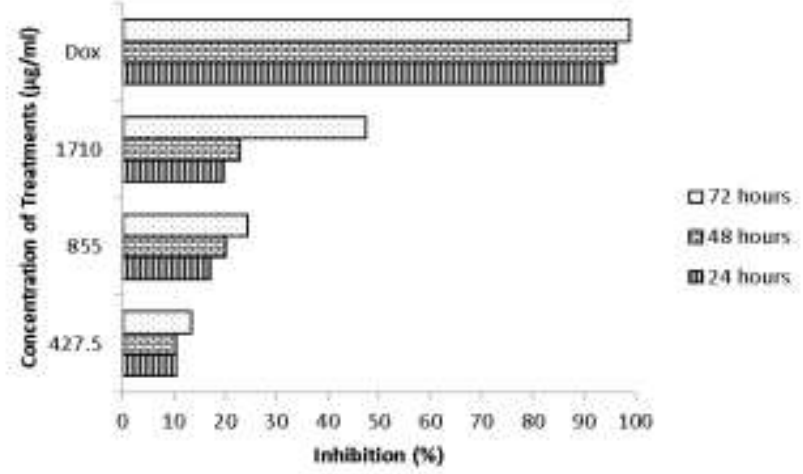

(a)

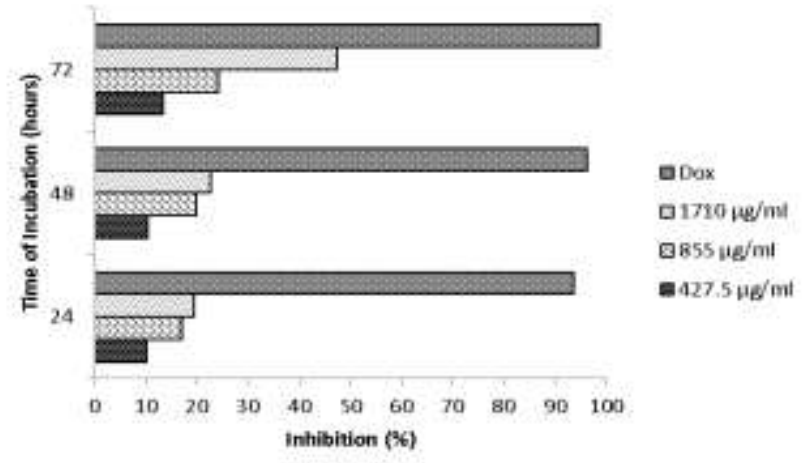

(b)

Figure 5. The inhibition activity of phycocyanin on WiDr cell in (a) vary treatments of doxorubicin, phycocyanin of $1710 \mu \mathrm{g} / \mathrm{ml} ; 855 \mu \mathrm{g} / \mathrm{ml}$; and $427.5 \mu \mathrm{g} / \mathrm{ml}$; (b) several incubation times of proliferation of 24,48 , and 48 hours. 
Cultivation is one of the effective methods to fulfill the demand for natural products. However, it is often a lack of targeted metabolites that lead to less effectiveness. As expressed in this study, the freshwater phycocyanin acted less effectual rather than marine phycocyanin as an anti-cancer agent (Czerwonka et al., 2018; Konícková et al., 2014; Zaid et al., 2015; Yohana et al., 2016).

Although many pieces of evidence through several studies postulated positive anti-cancer activity of phycocyanin, in this research, exceptional circumstances limited the multifunctional usage of phycocyanin, particularly to overcome colon cancer treatment. Thereafter the information could provide the new evidence of the contrary results of freshwater phycocyanin activity from Spirulina platensis as a chemopreventive agent. The results would be useful to develop an advanced technique to produce freshwater phycocyanin with anti-cancer activity as its wild type.

\section{CONCLUSION}

In conclusion, phycocyanin extracted from freshwater Spirulina platensis was classified as non-toxic $\left(\mathrm{IC}_{50}\right.$ of $\left.855 \mu \mathrm{g} / \mathrm{ml}\right)$. Consequently, it is less potential to be used as the treatment for colon cancer. However, phycocyanin slightly promotes anticancer activity by inhibiting the proliferation of the WiDr cell for approximately $47.4 \%$, significantly at the concentration of $1710 \mu \mathrm{g} / \mathrm{ml}$ for 72 hours. It can be concluded that freshwater phycocyanin is less effective as an anticancer substance of colon cancer.

\section{ACKNOWLEDGMENT}

The authors would like to thank the Ministry of Marine Affairs and Fisheries through the scholarship of "Pusat Pendidikan Kelautan dan Perikanan" in 2019, which has fully funded the research.

\section{REFERENCES}

AAT Bioquest, I. (2019). Quest GraphTM IC50 Calculator. Retrieved November 18, 2019, from https://www.aatbio.com/tools/ic50-calculator

Agustini, N. W. S. (2007). Aktivitas Antioksidan dan Uji Toksisitas Hayati Pigmen Fikobiliprotein dari Ekstrak Spirulina platensis. Seminar Nasional IX Pendidikan Biologi FKIP UNS, 1, 535-543.

American Type Culture Collection. (2019). WiDr (ATCC® CCL?218TM). Retrieved July 6, 2019, from www.atcc.org

Athauda, A., Segelov, E., Ali, Z., \& Chau, I. (2019). Integrative molecular analysis of colorectal cancer and gastric cancer: What have we learnt?. Cancer treatment reviews, 73, 31-40.
Cahyaningrum, Y. A. (2019). Uji Sitotoksik Ekstrak Etanol dan Metanol Alga Spirulina platensis Terhadap Sel Kanker Payudara T47D. Surakarta: Universitas Muhammadiyah Surakarta.

Czerwonka, A., Kaławaj, K., Sławińska-Brych, A., Lemieszek, M. K., Bartnik, M., Wojtanowski, K. K., Rzeski, W. (2018). Anticancer effect of the water extract of a commercial Spirulina (Arthrospira platensis) product on the human lung cancer A549 cell line. Biomedicine and Pharmacotherapy, 106(1), 292-302.

Dewi, I. C., Falaise, C., Hellio, C., Bourgougnon, N., \& Mouget, J. (2018). Anticancer, Antiviral, Antibacterial, and Antifungal Properties in Microalgae. In Microalgae in Health and Disease Prevention (pp. 235-261). Elsevier Inc.

Ekantari, N., Marsono, Y., Pranoto, Y., \& Harmayani, E. (2017). Pengaruh Media Budidaya Menggunakan Air Laut dan Air Tawar terhadap Sifat Kimia dan Fungsional Biomassa Kering Spirulina platensis The Effect of Cultivation Medium in Marine and Fresh Water on Chemical Composition and Functional Properties. Agritech, 37(2), 173-182.

Ekowati, H., Achmad, A., Prasasti, E., Wasito, H., Sri, K., Hidayati, Z., \& Ekasari, T. (2012). Zingiber officinale, Piper retrofractum, and Combination Induced Apoptosis and p53 Expression in Myeloma and WiDr Cell Lines. HAYATI Journal of Biosciences, 19(3), 137-140.

El-hack, M. E. A., Abdelnour, S., Alagawany, M., Abdo, M., Sakr, M. A., Khafaga, A. F., Gebriel, M. G. (2019). Microalgae in modern cancer therapy: Current knowledge. Biomedicine \& Pharmacotherapy, 111(1), 42-50.

Ercolano, G., Cicco, P. De, \& Ianaro, A. (2019). New Drugs from the Sea: Pro-Apoptotic Activity of Sponges and Algae Derived Compounds. Marine Drugs, 17(1), 31-36.

Fithriani, D., Amini, S., Melanie, S., \& Susilawati, R. (2015). Uji Fitokimia, Kandungan Total Fenol Dan Aktivitas Antioksidan Mikroalga Spirulina sp ., Chlorella sp ., dan Nannochloropsis sp. JPB Kelautan dan Perikanan, 10(2), 101-109.

Iqbal, J., Abbasi, B. A., Mahmood, T., Kanwal, S., Ali, B., \& Khalil, A. T. (2017). Plant-derived anticancer agents : A green anticancer approach. Asian Pacific Journal of Tropical Biomedicine, 7(12), 1129-1150.

Izadi, M., \& Fazilati, M. (2018). Extraction and purification of phycocyanin from spirulina platensis and evaluating its antioxidant and antiinflammatory activity. Asian Journal of Green Chemistry, 2(4), 364-379.

Karpisheh, V., Nikkhoo, A., Hojjat-farsangi, M., Namdar, A., Azizi, G., Ghalamfarsa, G., Jadidi- 
niaragh, F. (2019). Prostaglandin E2 as potent therapeutic target for treatment of colon cancer. Prostaglandins and Other Lipid Mediators, 144, 106338.

Konícková, R., Vanková, K., Vaníková, J., Vánová, K., Muchová, L., Subhanová, I., Strnad, H. (2014). Anti-cancer effects of blue-green alga Spirulina platensis, a natural source of bilirubin-like tetrapyrrolic compounds. Annals of Hepatology, 13(2), 273-283.

Luparello, C., Ragona, D., Asaro, D. M. L., Lazzara, V., Affranchi, F., Celi, M., Vazzana, M. (2019). Cytotoxic potential of the coelomic fluid extracted from the sea cucumber Holothuria tubulosa against triple-negative MDA-MB231 breast cancer cells. Biology, 8(4), 76.

Manirafasha, E., Murwanashyaka, T., Ndikubwimana, T., Rashid Ahmed, N., Liu, J., Lu, Y., Jing, K. (2018). Enhancement of cell growth and phycocyanin production in Arthrospira (Spirulina) platensis by metabolic stress and nitrate fed-batch. Bioresource Technology, 255, 293-301.

Mutiah, R., \& Widyawaruyanti, A. T. Y. (2017). Cytotoxic Effect of Crude Extract and Fraction From Calotropis gigantea Leaves on Human Colon Cancer WiDr Cell Lines. International Journal of Pharmacy and Pharmaceutical Sciences, 9(1), 8386.

Nazih, H., \& Bard, J. (2018). Microalgae in Human Health: Interest as a Functional Food. In Microalgae in Health and Disease Prevention (pp. 211226). Elsevier Inc.

Nikolova, B., Semkova, S., Tsoneva, I., Antov, G., Ivanova, J., Vasileva, I., Kabaivanova, L. (2019). Characterization and potential antitumor effect of a heteropolysaccharide produced by the red alga Porphyridium sordidum. Engineering in Life Sciences, 19(12), 978-985

Paliwal, C., Mitra, M., Bhayani, K., Bharadwaj, S. V. V., Ghosh, T., Dubey, S., \& Mishra, S. (2017). Abiotic stresses as tools for metabolites in microalgae. Bioresource Technology, 244(1), 12161226.

Papadaki, S., Kyriakopoulou, K., Tzovenis, I., \& Krokida, M. (2017). Environmental impact of phycocyanin recovery from Spirulina platensis cyanobacterium. Innovative Food Science and Emerging Technologies, 44(1), 217-223.

Rahmawati, S. I., Hidayatullah, S., \& Suprayatmi, M. (2017). Ekstraksi Fikosianin Dari Spirulina Plantesis Sebagai Biopigmen dan Antioksidan. Jurnal Pertanian, 8(1), 36-42.

Ravi, M., Tentu, S., Baskar, G., Prasad, S. R., Raghavan, S., Jayaprakash, P., Venkatraman, G.
(2015). Molecular mechanism of anti-cancer activity of phycocyanin in triple-negative breast cancer cells. BioMed Central Cancer, 15(1), 768-772.

Thangam, R., Suresh, V., Princy, W. A., Rajkumar, M., Senthilkumar, N., Gunasekaran, P., ... Kannan, S. (2013). C-Phycocyanin from Oscillatoria tenuis exhibited an antioxidant and in vitro antiproliferative activity through induction of apoptosis and G 0 / G 1 cell cycle arrest. Food Chemistry, 140(1-2), 262-272.

Udayan, A., Arumugam, M., \& Pandey, A. (2017). Nutraceuticals From Algae and Cyanobacteria. In Algal Green Chemistry (pp. 65-89). https://doi.org/10.1016/B978-0-444-637840.00004-7

Vo, T., Ngo, D., \& Kim, S. (2015). Nutritional and Pharmaceutical Properties of Microalgal Spirulina. Handbook of Marine Microalgae. Elsevier Inc. https://doi.org/10.1016/B978-0-12-8007761.00019-4

Widiyastuti, Y., Sholikhah, I. Y. M., \& Haryanti, S. (2019). Phytochemical and Cytotoxic Evaluation of Krangean Fruits Extracts Against HeLa, MCF7, and HepG2 Cancer Cell Line. Biosaintifika Journal of Biology \& Biology Education, 11(11), 304-310.

Wulandari, N., Meiftasari, A., Fadliyah, H., \& Jenie, R. I. (2018). Red Betel Leaves Methanolic Extract (Piper crocatum Ruiz \& Pav.) Increases Cytotoxic Effect of Doxorubicin on WiDr Colon Cancer Cells through Apoptosis Induction. Indonesian Journal of Cancer Chemoprevention, 9(1), 1.

Yang, F., Li, B., Chu, X.-M., Lv, C.-Y., Xu, Y.-J., \& Yang, P. (2014). Molecular mechanism of inhibitory effects of C-phycocyanin combined with alltrans -retinoic acid on the growth of HeLa cells in vitro. Tumor Biology, 35(6), 5619-5628.

Ying, J., Wang, J., Ji, H., Lin, C., Pan, R., Zhou, L., Li, P. (2016). Transcriptome Analysis of phycocyanin inhibitory effects on SKOV-3 cell proliferation. Gene, 585(1), 58-64.

Yohana, F., Hernandez, F., Khandual, S., Guadalupe, I., \& López, R. (2016). Cytotoxic effect of Spirulina platensis extracts on human acute leukemia Kasumi-1 and chronic myelogenous leukemia K562 cell lines. Asian Pacific Journal of Tropical Biomedicine, 7(1), 14-19.

Zaid, A. A. A., Hammad, D. M., \& Sharaf, E. M. (2015). Antioxidant and Anticancer Activity of Spirulina platensis Water Extracts. International Journal of Pharmacology, 11(7), 846-851. 